\title{
Cutaneous absorption of trivalent chromium: tissue levels and treatment by exchange transfusion
}

\author{
W F KELLY, ${ }^{1}$ P ACKRILL, ${ }^{1} \mathrm{~J}$ P DAY,${ }^{2}$ MAUREEN O'HARA,${ }^{2} \mathrm{C}$ T TYE, ${ }^{2}$ I BURTON,${ }^{3}$ \\ C ORTON, ${ }^{4}$ and M HARRIS ${ }^{5}$
}

From the Departments of Nephrology, ${ }^{1}$ Haematology, ${ }^{3}$ Plastic Surgery, ${ }^{4}$ and Histopathology, ${ }^{5}$ University Hospital of South Manchester (Withington Hospital), and Department of Chemistry, ${ }^{2}$ University of Manchester, Manchester, UK

\begin{abstract}
A man was accidentally immersed in hot acidic trivalent chromium sulphate solution but none was swallowed. The clinical course was dominated by burns, intravascular haemolysis, and acute renal failure. Blood concentrations of chromium were measured during treatment and tissue concentrations were measured at death. Exchange transfusion reduced blood chromium concentrations by two-thirds. The total quantities of chromium absorbed and removed by various routes were calculated. In-vitro studies showed that the chromium solution did not directly cause haemolysis.
\end{abstract}

Soluble compounds of chromium are widely used in industrial processes, including dyeing, electroplating, and leather tanning. ${ }^{1}$ Toxicity due to chromium salts includes hand ulcers, dermatitis, perforation of the nasal septum, and lung cancer. ${ }^{1}$ Ingestion of hexavalent chromium (chromate or dichromate salts) causes ulceration of the bowel, diarrhoea, and renal and hepatic damage. ${ }^{2-4}$ There are also a few reports of toxicity from hexavalent chromium when absorbed cutaneously. ${ }^{5}$ Toxic effects are found only with hexavalent chromium compounds, and trivalent compounds are relatively harmless. ${ }^{67}$ To remove chromium, together with the products of intravascular haemolysis, we used an exchange transfusion, which has not previously been reported.

\section{Case report}

The patient, a 56-year-old white man, had not previously suffered from serious illness or evidence of chromate toxicity. He was employed on an industrial process to make aqueous, acidic chromium (III) sulphate solution $\left(\mathrm{Cr}_{2}\left(\mathrm{SO}_{4}\right)_{3} 40 \% \mathrm{w} / \mathrm{w}\right)$ and $\mathrm{Na}_{2} \mathrm{SO}_{4}$, $8 \% \mathrm{w} / \mathrm{w}$, and $\mathrm{H}_{2} \mathrm{SO}_{4}$ at $\mathrm{pH} 2.83$ and $80^{\circ} \mathrm{C}$. He became accidentally immersed up to his neck in a vat of this fluid and sustained $70 \%$ burns of variable thickness to the skin of the limbs, thorax, and abdomen. The face and neck did not come into contact

Received 17 August 1981

Accepted 15 December 1981 with the fluid, and none was swallowed. He was transferred for intensive care; on arrival (two and a half hours after the accident) he was still conscious but shocked, with a pulse of $140 /$ minute. There was no buccal erythema or ulceration and no evidence initially of cardiac, hepatic, or renal failure. The first results two and a half hours after the accident were haemoglobin $15.9 \mathrm{~g} / \mathrm{dl}$, PCV 0.44, MCV $79 \mathrm{fl}, \mathrm{MCH}$ $28.4 \mathrm{pg}$, WCC $40 \times 10^{9} / 1$ (90\% neutrophils), reticulocytes $2 \%$, platelets $170 \times 10^{\%} / 1$. The blood film (fig 1) showed gross anisocytosis and red cell fragmentation with numerous microspherocytes. Plasma haemoglobin was $1.2 \mathrm{~g} / \mathrm{dl}$, prothrombin time $28 \mathrm{sec}$ (normal $12 \mathrm{sec}$ ), partial thromboplastin time $70 \mathrm{sec}$ (normal $37-45 \mathrm{sec}$ ), thrombinfibrinogen time $16 \mathrm{sec}$ (normal $11 \mathrm{sec}$ ), fibrinogen $1 \mathrm{~g} / 1$ (normal $2 \cdot 5-4.0 \mathrm{~g} / \mathrm{l})$, fibrin degradation products $11 \mathrm{mg} / \mathrm{l}$ (normal $<6 \mathrm{mg} / \mathrm{l}$ ). Plasma sodium was $136 \mathrm{mmol}$, potassium $6.2 \mathrm{mmol} / \mathrm{l}$, chloride $90 \mathrm{mmol} / \mathrm{l}$, bicarbonate $13 \mathrm{mmol} / \mathrm{l}$, urea $4.3 \mathrm{mmol} / \mathrm{l}$, creatinine 0.13 $\mathrm{mmol} / \mathrm{l}$, calcium $2.4 \mathrm{mmol} / \mathrm{l}$, glucose $16.0 \mathrm{mmol} / \mathrm{l}$, bilirubin $29 \mu \mathrm{mol} / 1$ (normal 3-19 $\mu \mathrm{mol} / \mathrm{l}$ ), aspartate transaminase 298 IU/1 (normal 6-50 IU/l). Arterial blood gases, breathing air, were $\mathrm{PO}_{2} 113 \mathrm{~mm} \mathrm{Hg}$, $\mathrm{PCO}_{2} 21 \mathrm{~mm} \mathrm{Hg}$. Urine microscopy showed 28 white cells and $>100$ red cells $/ \mathrm{mm}^{3}$. Sputum culture grew Streptococcus pneumoniae and blood cultures grew Escherischia coli and Strep pneumoniae. The first chest radiograph was normal. Intravenous therapy was given and in the next $\mathbf{4 4}$ hours before death, in addition to the exchange transfusion, he 


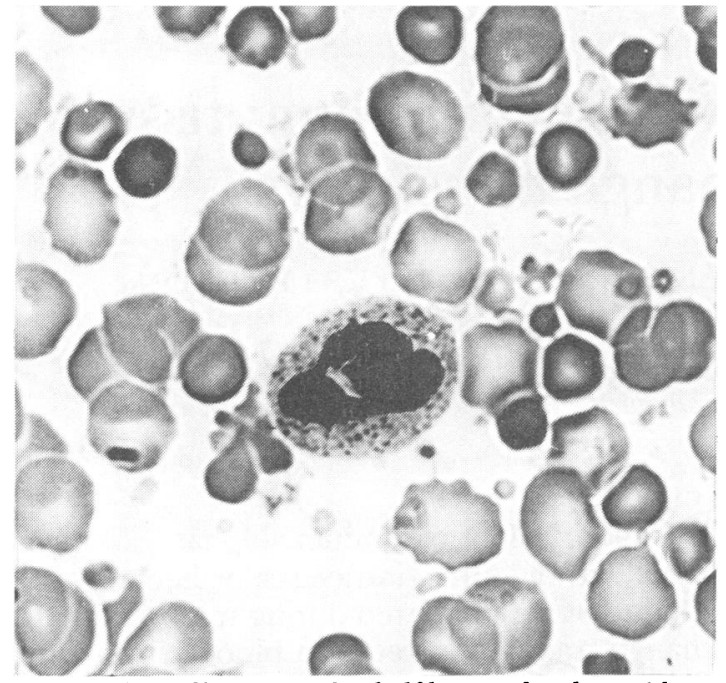

Fig 1 Blood film two-and-a-half hours after the accident.

had 27.21 as follows: 11.81 of electrolytes (mainly physiological saline), 11.41 plasma, 3.5 I blood, 0.41 fibrinogen, and $0 \cdot 11$ of platelets. Other treatments included intravenous frusemide total $2 \mathrm{~g}, 70 \mathrm{ml}$ of $1 \%$ aqueous solution of methylene blue intravenously to reduce any hexavalent chromium, ethylene diamine tetra-acetic acid $10 \% \mathrm{v} / \mathrm{v}$ in $0.9 \%$ saline topically to minimise by chelation the absorption of chromium, and cimetidine $200 \mathrm{mg}$ intravenously every four hours as prophylaxis against peptic ulceration, plus antibiotics.

His condition deteriorated severely with oliguric renal failure (urine volume $230 \mathrm{ml}$ in first 24 hours, falling to $40 \mathrm{ml}$ in the next 20 hours). In view of the continuing intravascular haemolysis and acute renal failure a Scribner arteriovenous shunt was inserted and an attempt was made to remove chromium by exchange transfusion of 10.91 of blood between the 33rd and 38th hour of the illness. At 38 hours haemoglobin was $11 \mathrm{~g} / \mathrm{dl}$, urea $19.8 \mathrm{mmol} / \mathrm{l}$, and arterial $\mathrm{PO}_{2}$ on $70 \%$ inspired oxygen $46 \mathrm{~mm} \mathrm{Hg}$. Forty-seven hours after the accident he died.

\section{Material and methods}

Blood samples for assay of chromium were collected into heparinised containers and the plasma and cells were separated and kept at $-20^{\circ} \mathrm{C}$ together with samples of urine and faeces until just before analysis. Tissue samples obtained at necropsy done 28 hours after death were kept at $-20^{\circ} \mathrm{C}$. Control samples of tissue were obtained from a patient who had a necropsy on the same day, using the same instruments (after washing) as our patient. Control samples of blood were obtained from a healthy volunterer. Triplicate portions of tissue $(0.2$ to $0.5 \mathrm{~g})$ and blood $(0.5 \mathrm{ml})$ were ashed with nitric acid. Residues were analysed by atomic absorption spectrometry using graphite furnace atomisation. ${ }^{8}$ All results quoted are the means of triplicate determinations. Analytical accuracy is estimated at \pm 0.02 $\mu \mathrm{g} / \mathrm{g}$ for both blood and tissue.

We obtained from the manufacturers a sample of the solution into which our patient was immersed. After adjusting to physiological $\mathrm{pH}$, the solution was added to human blood in vitro to give chromium concentrations from 0.1 to $1 \mathrm{mg} / \mathrm{ml}$ and left at $37^{\circ} \mathrm{C}$ for 24 hours, and then the presence or absence of haemolysis and formation of Heinz bodies and burr cells were noted.

\section{Results}

Figure 2 shows the results of assays for chromium in blood. The chromium concentration in plasma exceeded that in red cells by a factor of 10 . Plasma concentrations of chromium declined fairly rapidly for the first few hours, but this process later slowed down. The highest concentration of chromium, 47 $\mu \mathrm{g} / \mathrm{ml}$, obtained five and a half hours after exposure, showed that at least $176 \mathrm{mg}$ of chromium was absorbed through the skin, assuming a plasma vol-

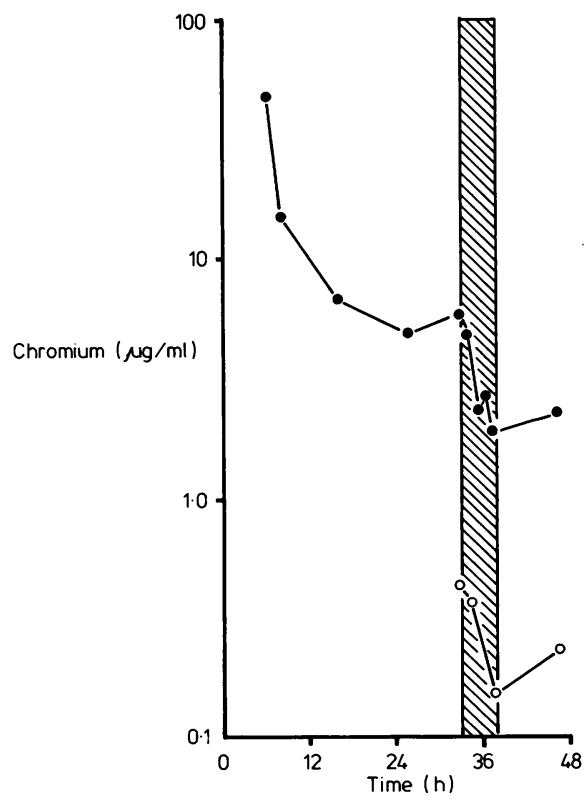

Fig 2 Results of assays for chromium in blood. - - plasma; $\bigcirc-O$ red cells. Hatched area denotes exchange transfusion. 
Chromium content of tissues at necropsy

\begin{tabular}{|c|c|c|c|c|c|}
\hline \multirow[t]{3}{*}{ Material } & \multicolumn{2}{|c|}{ Chromium ( $\mu g / g)$} & \multirow{3}{*}{$\begin{array}{l}\text { Concentration } \\
\text { ratio }\end{array}$} & \multicolumn{2}{|c|}{ Chromium ( $\mu \mathrm{g} / \mathrm{g})$} \\
\hline & \multicolumn{2}{|l|}{$\begin{array}{l}\text { Our patients } \\
\text { Chromium }\end{array}$} & & \multicolumn{2}{|c|}{ Patients of Fritz et al ${ }^{\mathrm{s}}$} \\
\hline & toxicity & Control & & 1 & 2 \\
\hline Skin severely burnt & 724 & - & - & $6 \cdot 7$ & - \\
\hline Skin slightly burnt & $3 \cdot 8$ & - & - & & - \\
\hline Skin not burnt & 1.8 & $1 \cdot 1$ & $1 \cdot 6$ & - & 0.9 \\
\hline Kidney & $16 \cdot 8$ & $1 \cdot 1$ & $15 \cdot 3$ & $12 \cdot 0$ & $5 \cdot 4$ \\
\hline Faeces & 12.4 & 0.2 & 59 & - & - \\
\hline Spleen & $7 \cdot 5$ & $<0.05$ & $>150$ & $10 \cdot 6$ & $4 \cdot 2$ \\
\hline Liver & $5 \cdot 5$ & $<0.05$ & $>110$ & $8 \cdot 9$ & $1 \cdot 5$ \\
\hline Bone & $5 \cdot 5$ & $<0.05$ & $>110$ & $8 \cdot 0$ & - \\
\hline Lung & $4 \cdot 7$ & 0.3 & 15.7 & $8 \cdot 5$ & 3.9 \\
\hline Heart & $1 \cdot 5$ & $0 \cdot 2$ & $7 \cdot 2$ & $2 \cdot 5$ & 0.8 \\
\hline Duodenal contents & 1.4 & - & - & - & - \\
\hline Muscle & 0.6 & $<0.05$ & $>12$ & $1 \cdot 3$ & $0 \cdot 5$ \\
\hline Brain & $<0.05$ & $<0.05$ & - & $0 \cdot 3$ & $0 \cdot 3$ \\
\hline
\end{tabular}

ume of 3.751 . Urinary output rapidly diminished after the first six hours, during which $10.5 \mathrm{mg}$ chromium was excreted; only trivial amounts of chromium $(<2 \mathrm{mg} / 24 \mathrm{~h})$ were excreted in the urine after this. The total quantity of chromium present at death, calculated from analysis of tissues at necropsy (table), was about $155 \mathrm{mg}$, assuming a normal body composition.' The total amount of chromium absorbed may therefore be estimated as follows: body burden at death (155 mg), plus amount removed by exchange transfusion (15 $\mathrm{mg})$, and excreted in urine $(12 \mathrm{mg}$ ) and faeces $(3 \mathrm{mg})$, giving a total of $185 \mathrm{mg}$, in reasonable agreement with the blood load of chromium at five and a half hours (176 $\mathrm{mg}$ ). The body burden at death was about $84 \%$ of the total chromium absorbed. High concentrations of chromium were found in the most severely damaged skin, but we have not included this in calculating the body burden, since the weight of the tissue affected was impossible to assess.

The effect of exchange transfusion was to lower the plasma concentration of chromium by $67 \%$ (from 5.9-1.9 $\mu \mathrm{g} / \mathrm{ml}$ ) and to lower the red cell concentration by $65 \%$ (from $0.43-0.15 \mu \mathrm{g} / \mathrm{ml}$ ), over five hours, and the rate of removal from blood was greatly increased by this procedure (fig 2). During the eight hours after completing the exchange transfusion there were increases both in plasma and red cell concentrations of chromium. The quantity of chromium removed by exchange transfusion was $15.3 \mathrm{mg}$, most of this $(15.0 \mathrm{mg})$ from plasma and only a trace $(0.3 \mathrm{mg})$ from red cells.

Sequential blood films showed a decrease in the proportion of fragmented red cells even before the exchange transfusion began, with further improvement at the end. In addition, there were improvements in the coagulation abnormalities; at the start and finish of the exchange the prothrombin times were 26 and $17 \mathrm{sec}$ respectively (normal $11-13 \mathrm{sec}$ ). In-vitro studies with the chromate solution and normal human blood showed no evidence of haemolysis and no Heinz body formation, but some burr cell formation was seen.

Necropsy showed $70 \%$ skin burns of variable thickness; pulmonary oedema; small haemorrhages on the tongue, oesophagus, ileum, and colon. Stomach and duodenum, liver, and heart were macroscopically normal; there was slight oedema of the cerebral hemispheres. Histological findings were: skin-no inflammatory reaction in the burnt areas but the underlying muscle was haemorrhagic; kidneys - mild interstitial oedema, dilatation and degeneration of the convoluted tubules, and granular and red cell casts in the collecting tubules; lungs-acute congestion; liver-swelling of centrilobular hepatocytes; small intestine and colonmucosal necrosis; trachea and bone marrownormal. There was evidence of disseminated intravascular coagulation.

\section{Discussion}

Since no oral absorption of chromium occurred, we may therefore compare and contrast our patient with two cases reported by Fritz et al in $1960 . .^{5}$ The clinical course in all three patients included renal failure. Patient 1 of Fritz et al was treated by peritoneal dialysis, and if our patient had survived longer he would have been given haemodialysis.

The extent and severity of burns in our patient were sufficient by themselves to have caused acute renal failure. Hexavalent chromium can cause acute renal failure, ${ }^{2-5}$ but trivalent chromium, to which our patient was exposed, is non-toxic. ${ }^{67}$ The tissue distribution of chromium was similar in the three patients with high concentrations in kidney and 
spleen and much lower concentrations in muscle and brain (table). The concentration of chromium found in tissues correlated with the damage sustained. In our patient there was no increase in brain chromium, and he remained conscious and orientated. The total body burden of chromium $(155 \mathrm{mg})$ was about 26 times the normal quantity of $6 \mathrm{mg} .{ }^{10}$ Blood concentrations of chromium were reduced by two-thirds by exchange transfusion (our patient), and by one-third by haemodialysis (patient of Fristedt $\left.e t a l^{3}\right)$. The amount of chromium removed by these means, however, is small compared with the total body content of chromium.

In vitro we were unable to show haemolysis with the chromic solution, so haemolysis in life was probably due to a combination of direct thermal injury to red cells and mechanical fragmentation of red cells in damaged capillaries. ${ }^{112}$

High concentrations of chromium were found in severely damaged skin, and this may have been a depot from which chromium could still enter the blood, explaining the secondary increase in blood concentrations of chromium after the exchange transfusion. Possibly a far larger quantity of chromium would have been removed had plasma exchange been implemented at an earlier stage, with consequently less chromium available for uptake by the body tissues.

In conclusion, immediate plasmapheresis together with early excision of all chromium-containing skin may minimise absorption of chromium in a patient with extensive skin burns and chromium contamination.

We thank our other colleagues including $\mathrm{Dr}$ A J Ralston, Dr P Penna, and Dr E Gowland for help in managing this patient.

\section{References}

' Hunter D. The diseases of occupations. 6th ed. London: Hodder and Stoughton, 1978:432-8.

${ }^{2}$ Goldman M, Karotkin RH. Acute potassium bichromate poisoning. Am J Med Sci 1935;189:400-3.

${ }^{3}$ Fristedt B, Lindqvist B, Schütz A, Övrum P. Survival in a case of acute oral chromic acid poisoning with acute renal failure treated by haemodialysis. Acta Med Scand 1965;177:153-9.

4 Kaufman DB, DiNicola W, McIntosh R. Acute potassium dichromate poisoning. Am J Dis Child 1970;119:374-6.

${ }^{5}$ Fritz KW, Böhm, P, Buntru G, Lowen CH. Die Akute Gewerbliche Dichromatvergiftung und Ihre Behandlung. Klin Wochenschr 1960;38:856-61.

- Underwood EJ. Trace elements in human and animal nutrition. New York: Academic Press, 1977:258-70.

${ }^{7}$ Sax NI. Dangerous properties of industrial materials. 5th ed. New York: Van Nostrand Reinhold Co, 1979.

${ }^{8}$ Tye CT. Manchester: Analytical methods for chromium and barium in environmental and clinical materials. University of Manchester, 1979. (MSc thesis.)

${ }^{\natural}$ Diem K, Lentner C, eds. Documenta Geigy, scientific tables. 7th ed. Basle: Geigy SA, 1970.

${ }^{10}$ Schroeder HA, Balassa JJ, Tipton IH. Abnormal trace metals in man - chromium. J Chron Dis 1962;15:941-64.

" Baar S, Arrowsmith J. Thermal damage to red cells. J Clin Pathol 1970;23:572-6.

12 DeGruchy GC. Clinical haematology in clinical practice, 3rd ed. Oxford: Blackwell Scientific Publications, 1970:348-50. 